HOW

Volume 28, Number 2, pages 11 - 31

https://doi.org/10.19183/how.28.2.598

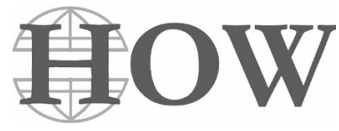

\title{
Local Epistemological Perceptions that Underlie EFL Literature and Teaching Practices in Colombia
}

\author{
Percepciones epistemológicas de la enseñanza del inglés como \\ lengua extranjera en Colombia
}

\author{
Martha Isabel Bonilla-Mora ${ }^{1}$ \\ Johanna Patricia López-Urbina ${ }^{2}$
}

\begin{abstract}
This study aims to understand the local and updated epistemological perceptions of the teaching and learning of English as a foreign language (EFL) in Colombia from the voices of English language university teachers. This qualitative research emerges as part of a hermeneutical perspective which allowed the authors to analyze experiences, perceptions, and understandings of teachers in the foreign language-teaching field. Data collection instruments included a literature review using framework matrices and semi-structured interviews. After data analysis, three categories emerged: Pertinence and Relevance of Teaching and Learning of EFL, Teaching and Learning of EFL, and The State of Bilingualism. The study concludes with the recommendation of promoting the teaching and learning of foreign languages based on contextualized necessities of Colombia. We draw attention to the cultural and linguistic diversity in our country. In addition, we raise awareness among preservice teachers towards an epistemological reconstruction that involves the ecology of knowledge, engaging them in critical knowledge and practices from outside the Eurocentric vision.
\end{abstract}

Keywords: bilingualism, Colombia, epistemology, foreign languages, language policy

She is an EFL teacher and researcher at Licenciatura en Lengua Extranjera Inglés at Universidad Santo Tomás, Colombia. She holds a master's degree in education from Universidad Pedagógica Nacional. Her research works mainly core on the narratives about the English teaching and learning contexts in Colombia. marthabonilla@ustadistancia.edu.co

ORCID ID: https://orcid.org/0000-0002-8823-2505

She is a teacher at Licenciatura en Lengua Extranjera Inglés at Universidad Santo Tomás, Colombia. She holds a BA in Philology and Languages and a Master's Degree in Education. She has worked with teachers and pre-service teachers in the rural and urban areas in Colombia.

Johanna.lopez@ustadistancia.edu.co

ORCID ID: https://orcid.org/0000-0002-1293-8042

Received: July 25th, 2020. Accepted: April 29th, 2021.

This article is licensed under a Creative Commons Attribution-Non-Commercial-No-Derivatives 4.0 International License. License Deed can be consulted at https://creativecommons.org/licenses/by-nc-nd/4.0 
Martha Isabel Bonilla-Mora,

Johanna Patricia López-Urbina

\section{Resumen}

Este estudio busca comprender las percepciones epistemológicas de la enseñanza y el aprendizaje del inglés como lengua extranjera (EFL) en Colombia a partir de la vOZ de algunos profesores de inglés. Esta investigación cualitativa surge desde una perspectiva hermenéutica que permitió a los autores analizar experiencias, percepciones y comprensiones de los docentes en el campo de la enseñanza de lenguas extranjeras. Los instrumentos de recolección de datos incluyeron una revisión de la literatura utilizando matrices analíticas y entrevistas semiestructuradas. Después del análisis, surgieron tres categorías: Pertinencia y relevancia de la enseñanza y el aprendizaje de EFL, Enseñanza y aprendizaje de EFL y, El estado del bilingüismo. Se concluye con la necesidad de promover la enseñanza y el aprendizaje de lenguas extranjeras en función de las necesidades contextualizadas, prestando atención a la diversidad cultural y lingüística en nuestro país. Así mismo, se reitera la importancia de sensibilizar a los docentes en formación hacia una construcción epistemológica que implique la ecología del conocimiento que los incluya dentro de un conocimiento crítico, apartado de la visión eurocéntrica.

Palabras clave: epistemología, Colombia, política lingüística, lenguas extranjeras, bilingüismo

\section{Introduction}

English as a foreign language (EFL) has been taught in Colombia from the perspective and the orientation of foreign beliefs, methodologies and under the implementation of policies created by the Ministry of National Education (MEN in Spanish) (Ramírez, 2015). These policies have been framed by the standards and competences outlined in the Common European Framework of Reference for Languages (CEFR). Although it is true that these policies have had good intentions to raise the development of society as a principle, the adoption of foreign educational and evaluative ideologies and dynamics have not been adapted to the Colombian context (Ramírez, 2015). On the contrary, the different educational actors have been forced to accept and apply them, even when our context, and even other Latin American contexts, do not meet the same initial conditions in their application process if social, economic, or cultural aspects are considered.

Even though the MEN indicates that learning a language is meant to achieve social equality (MEN, 2006), in practice this has not materialized. A clear illustration can be seen in the different national bilingualism plans established for the 2018-2022 four-year period.

Resaltar el reconocimiento de que el país ya posee una riqueza cultural y lingüistica inmensa, lo que nos hace un país multilingüie y multicultural que reconoce sus lenguas nativas y criollas, mientras le abre las puertas a la construcción de ciudadanía global a través de las lenguas extranjeras. ${ }^{3}$ (Colombia Aprende, 2016, Conoz̧ca el Plan de Bilingüismo, para. 3)

To highlight the recognition that the country already has an immense cultural and linguistic wealth, which defines us as a multilingual and multicultural country that recognizes its native and Creole languages, while opening the doors to the construction of global citizenship through foreign languages. 
Although the policy recognizes the multiculturalism of Colombia, the level of investment and promotion in teaching and learning either the native language or others has been scarce and faint. An example of the above is that now there are no official documents that promote the learning of other languages as there exist for the teaching and learning of English. It is concluded here that naming aspects of multiculturalism, which in our country is based and enriched on our cultural diversity and the coexistence of different cultures in the national territory, and multilingualism, defined as the use of more than one language in a community or territory (Hakuta, 2009), does not mean that all the knowledge of the territory is being recognized and included in that purpose of social equality.

All of the above brought the authors to reflect on the fact that in spite of English having been taught officially in Colombia for more than three decades (Bastidas, 2017), the efficacy and quality of teaching and learning in the country have not been successful. Therefore, it is crucial to inquire in local and updated epistemological bases in the Teaching and Learning of English as a Foreign Language (TLEFL) and how these findings could foster teachers' movement toward new horizons. Thus, the authors of this current article aimed to answer the following question: What are the local epistemological perceptions that underlie the teaching and learning of EFL in Colombia nowadays?

\section{Epistemology of Teaching and Learning English as a Foreign Language (TLEFL)}

To define the epistemology that underlies the TLEFL, we will refer to Cohen who affirms: "Epistemology is concerned with the nature and forms of knowledge and the epistemological assumptions about how knowledge can be created, acquired and communicated, in other words what it means to know" (2007, as cited in Scotland, 2012, p. 7). In agreement, Guba and Lincoln (2012, as cited in Scotland, 2012) assert that epistemology establishes indissolubly tangled relations between the knower and the knowledge; that is why epistemology asks the question about the nature of the relationship between the would-be knower and what can be known. Assenting to Goldman (1986, as cited in Watson-Gegeo, 2004), epistemology refers to the theory of knowledge and theorizing knowledge; it is concerned with who can be a knower, what can be known, what constitutes knowledge, and sources of evidence for constructing knowledge.

Soleimani (2018) states that epistemological beliefs describe individual representations about knowledge and knowing and about the epistemology in the class. In other words, the idea of classroom management originated from child development theories based on different teachers' approaches to classroom management. Regarding the teaching style, the personal tendencies toward learning and pedagogy might be manifested differently in diverse contexts. 
Wallace (1991, as cited in Soleimani, 2018) refers to two types of trainee knowledge: The theoretical knowledge and the knowledge in action. The first knowledge is accepted without question; this knowledge includes the teaching terminology as methodologies and approaches. The second knowledge is what teachers learn through classroom situations and reflections on their experience. Schommer, Chan, and Elliott (2004, as cited in Soleimani, 2018) declare that the epistemological belief system contains five dimensions: 1) certainty of knowledge, 2) structure of knowledge, 3) source of knowledge, 4) control of knowledge, fixed to changing and dynamic ability to learn something, and 5) speed of knowledge acquisition quick to gradual knowledge acquisition. Those beliefs play a decisive role regarding how a teacher interprets knowledge, justifies the structure and source of information, and more generally, how the learning process expands.

However, languages are not used in a vacuum chamber nor do they exist without any context; they are used for responding to the reception of discursive contexts that are necessarily always impregnated with the ideology of social systems and institutions (Vez, 2010). Hence, understanding the ideology and the social system in which knowledge of English surfaced is necessary. Junca (2016) describes four occurrences that embrace the cultural, social, and economic complexities of the English as a foreign language knowledge and knowing. Junca (2016) explains that the system of the English language emerges because of the constitution of a language as a privilege under the category of universality. The universality of the communicative approaches is enhanced by center-based textbook editorials which foster the use of certain methods and techniques by means of training sessions offered by the publishing houses for using the books. Opposite to this idea, Kincheloe (2004, as cited in Granados-Beltran, 2018b) states that human knowledge construction does not lead to universal truths nor can it be considered an objective linear process.

The second event refers to the processes of colonization that fostered the idea of English as a cultural prestige language. In the third occurrence, the literature is positioned as an aesthetic canon and as statute for knowledge. Regarding the fourth occurrence, Junca (2016) affirms that American economics, lifestyles, culture, and interpersonal relationships became a frame of reference that the global system expanded across the globe. Consequently, the official language of Colombia was disseminated in the same way, ratifying itself as predominant in the stratification of languages. These discourses foster the instrumentalization and standardization of foreign language teaching and learning, so English knowledge and knowing is reduced to a statute of truth, productivity, accessibility, global economy, and political coercion.

\section{Teachers and Teaching Epistemology}

In agreement with Soleimani (2018), English language teachers' epistemological beliefs describe the individual representations about knowledge. This means that beliefs are the 
engine that triggers values, individual behavior, and knowledge acquisition; facts that determine what teachers do and how they behave in classroom. Donmoyer (2001, as cited in Soleimani, 2018), declares there are some determinant elements defining how a teacher reacts in a classroom and, as well, that make up part of the epistemological beliefs that correspond to the way a teacher interprets knowledge, the approach the teacher follows, and the teacher's style. Kincheloe (2004, as cited in Granados-Beltran, 2018b) explains that the way teachers teach, just as their pedagogical purposes, is tied to how teachers see themselves.

This means that teachers confront themselves with their thoughts and beliefs and about their role as teachers and, in general, the construction of their link to the social, political, economic, and cultural world around them. Unfortunately, and because language teaching in Colombia has been accomplished under the European and North American coloniality of knowledge, the teaching and learning epistemological beliefs, and their representations of knowledge have been shortened and replaced by foreign institutions whose native speakers design, train, and certify teachers. Thus, the teaching and learning are seen as a weak and little explored field that does not have strong foundations and ends up adopting foreign methodologies. The epistemological approach to language keeps being prescriptive thus fostering passive minds and leaving no space for teachers to break with the hegemony of English.

\section{Recent Historical Background and Policies in Teaching and Learning English in Colombia}

Colombia is a diverse and pluricultural country in South America and it is proud of its great biodiversity, with enormous energy resources, and multicultural people (Bonilla, Lopez, \& Caro, 2018). However, an army conflict, which has lasted for more than fifty years, and poor economic conditions have driven the country's population and indigenous communities to concentrate in the main Colombian cities. This exodus caused the migrating people to forget their knowledge, their language and culture and favor the acquisition of new imposed knowledge. Regarding the languages teaching and learning, the country has been dominated by external linguistic, social, and economic agendas. Usma (2009) asserts that Colombian language policies and reform agendas can be traced to the times of the colony. He also acknowledges that these processes made possible the externalization of discourses, and the stratification of languages, groups, and cultures.

Different actors have been involved in the transition period of English as a foreign language in the national education system: the European Union, the Council of Europe, the British Council, the Centro Colombo Americano and the MEN. All of them have implemented different policies with the purpose of improving the teaching and learning of 
foreign languages in our country (Bastidas, 2017; Bonilla-Carvajal \& Tejada-Sánchez, 2016; Bonilla et al., 2018; Usma Wilches, 2009; Vez, 2010).

By 1991, the National Constitution of Colombia introduced the recognition of decentralization and the autonomy of municipal and departmental entities; the recognition of multiculturalism, pluri-ethnicity, and the autonomous rights of indigenous and black peoples; the recognition of equality for all religions and cults; the primacy of human rights over religious ones. Later, on February 8, 1994, the MEN launched General Law of Education 115. The law 'reorganized the whole school system and established specific goals for foreign languages in the country' (Usma Wilches, 2009, p. 3). This law proposed new curricular guidelines for foreign languages; this meant that methods and approaches were given to the teachers, limiting their autonomy (Usma Wilches, 2009). On the one hand, Law 115 recognized the decentralization and the autonomy of municipal and departmental entities, multiculturalism, and pluri-ethnicity, but the authors observe a disconnection between the concept of native and foreign language and their learning process (Law 115, 1994).

These aspects have remained in the subsequent laws for language education and National Bilingualism Programs, this last one undergoing slight modification in name and constructs but exhibiting low recognition of the cultural characteristics of our country, as well as the marginalization of proper communities and languages that exist in the territory. Bonilla-Carvajal and Tejada-Sánchez (2016) state that the bases of previous policies adhered to the socio-economic context to make the teaching and learning of English more technical, scientific, and efficient.

Along with this brief historical account, it has been demonstrated that despite the new discourses, policies, practices, and linguistic policies, the aim to turn Colombia into a bilingual country has failed to materialize.

\section{Method}

To answer the question about what the local epistemological perceptions that underlie the teaching and learning of EFL in Colombia are nowadays, this research study followed the principles of qualitative research, which in Creswell's words (2013) studies a problem

16 addressing the meaning individuals or groups ascribe to a social or human problem. In addition, this qualitative study emerges as part of a hermeneutical perspective which is defined as the science or art of interpretation with three basic meanings: express, explain and translate (Ferraris, 1996); this aspect allowed the authors to understand a problem, its definition, and the reconfiguration of new facts from a holistic and descriptive perspective.

On the other hand, the epistemological assumption intends to depict what counts as knowledge and how it is justified (Creswell, 2007). That is why the authors conducted this 
study based on the experiences, perceptions, and understanding of people in the foreign language-teaching field with the purpose of contributing to the literature or calling for a change regarding two aspects: pedagogical aspects related to EFL teaching and learning, and research in EFL teaching and learning.

The data collection instruments included: a literature review of framework matrices on historical, statistical, and official documents, study reports, scientific articles, and press items, among others. They originated to make a critical analysis of the existing theory on TLEFL in our country. From this literature analysis, the research participants who were interviewed were subsequently defined.

Semi-structured interviews were applied to a purposive sampling of experts in EFL in Colombia to validate information found in the literature review and to dig deeper into aspects that required further exploration. Regarding the experts, we invited all of those who had published academic articles related to the historical and normative Colombian EFL background and expressed their agreement to being interviewed. Interviews included questions related to (a) the importance of learning EFL in Colombia, (b) approaches, methods, and methodologies implemented in the process of learning and teaching English in public and private schools, (c) perception of the National Education Policies of teaching and learning English in Colombia, (d) bilingualism in Colombia, and (e) aspects to consider in designing public linguistic and education policies in Colombia.

\section{Participants}

Our purposive sample of participants comprised expert researchers in the field of EFL, teachers from secondary and higher education, and two experts from the MEN in Colombia. The study included 13interviews: 11 university teachers (six of them hold PhDs and 6 hold Master studies related to the EFL education field) and two members of the MEN. Interviews were carried out during the second semester of 2018. Participants were informed of the confidentiality of the interview to protect their anonymity.

\section{Data Analysis}

The processes of data collection, data analysis, and report writing are not distinct steps in the process - they are interrelated and often go on simultaneously in a research project (Creswell, 2007). That is why in this study, the authors decided to carry out the following phases:

a) Interviews and framework matrices analysis: For this first analysis phase, the authors explored extant texts like, MEN official documents, policies, literature, and research 
articles and those allocated in official websites. As a second step, framework matrices were designed as the first instrument of analysis to treat them as an analytical and supplementary source of data and to situate them in context (Charmaz, 2006). In this step, the authors explored the information of the 13interviews collected.

b) The authors analyzed the data following an initial coding to define what was happening in the data and to understand what they meant. Generalizations and concepts emerged from an examination of the raw data grounded in the context itself, rather than verifying predetermined hypotheses; the open coding procedures allowed us to cover new relationships, concepts, and understandings.

c) Organization of analyzed data: Based on the previous matrices, the authors carried out a first triangulation theoretical process, and later a peer review or debriefing process among the members of the research group (Creswell \& Miller, 2000).

\section{Results}

During the process of analysis and categorization, the authors distinguished three vertical levels of categories. In the first level, the authors introduced the central inquiry that occupied this research, while in the second level, they introduced category one, Pertinence and Relevance of the Teaching and Learning of EFL; category two, Teaching and Learning of EFL; and category three, the State of Bilingualism. Once the authors revisited the early categorization and examined connections among the categories, sub-categories emerged. Thus, from the first category, two subcategories emerged, English power and English prestige; from the second category, four subcategories emerged, (a) pedagogy, didactic and linguistics, approaches and methods, (b) the teaching and evaluation standards; (c) Colombian English teachers' identities; and (d) contexts. The following figure illustrates the three main categories and the subcategories. These three categories helped the authors to answer the question: What are the local epistemological perceptions that underlie the teaching and learning of EFL in Colombia nowadays?

\section{The Pertinence and Relevance of Teaching and Learning EFL in Colombia}

\section{Power}

According to the information gathered, the authors inferred that TLEFL in Colombia implies a powerful benefit in the eyes of the world. Teachers, students, administrators, and parents believe that people around the world must speak English and so this language started 


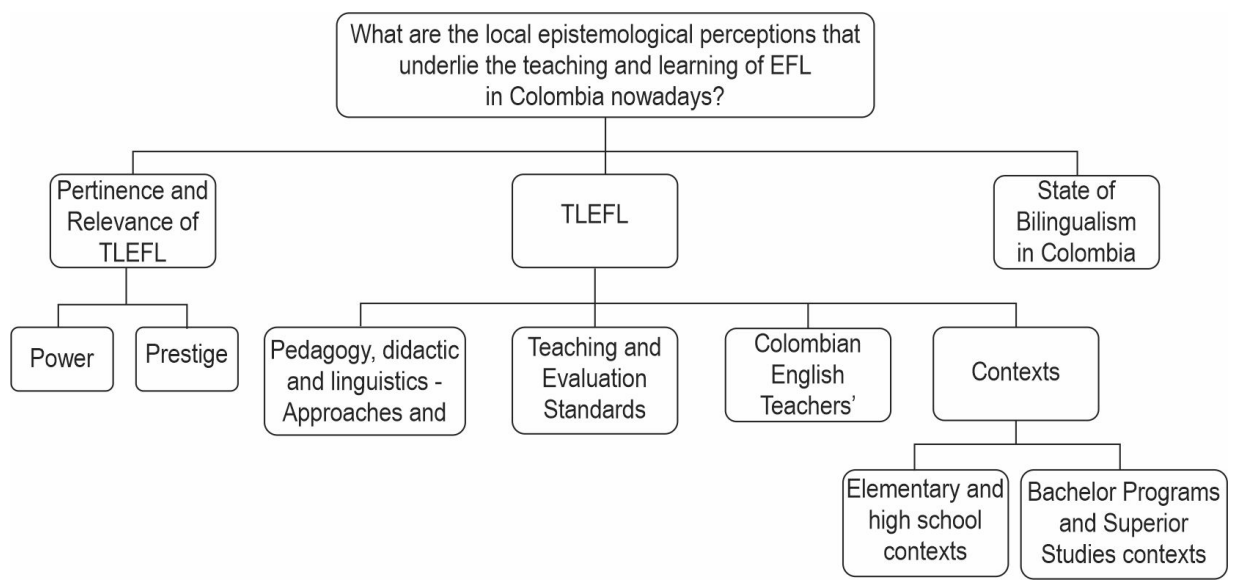

Figure 1. Categories

to be considered as a 'universal language'. In fact, this led the country to adopt policies that positioned the hegemony of English as being without question the universality of English (Ramírez, 2015). A good example of this acceptance is clearly displayed in the main goal of the NPB 'to have citizens who are able to communicate in English with international standards, so that they can introduce the country to the processes of universal communication, the global economy, and cultural openness' (Ramírez, 2015, p. 33).

The interest in including English as a foreign language in the curriculum occurred thanks to the globalization movements in which the country has been immersed. This contributed to the diffusion of English, which means the dominance of English as an international language, leaving aside the recognition of the cultural characteristics of our country, as well as the marginalization of proper communities and languages that exist in the territory.

Interviewee 1 explains how English was inserted in the higher education curriculum:

"Around mid-60s universities began to demand English classes for the different careers. However,

in Colombia this requirement was evident by 30s, when the language Institutes implemented the English teaching and learning programs; that started with the private institutes then applied in the public ones." (INTVW. 1)

In agreement, Interviewee 3 affirms that TLEFL in Colombia has been a matter of fulfilling governmental and economic goals: 
"This could be the origin of integrating a well-regarded language like English in the curriculum, thereby excluding the native languages. But why to be bilingual only between Spanish-English? Why a prestigious bilingualism? In this University, we have students that belong to indigenous communities but also to a minority group that communicate through sign language. So, as a country, we must understand that bilingualism cannot be reduced to a prestigious bilingualism." [sic] (INTVW 3)

\section{Prestige}

English was also considered a basic good that gave one prestige. According to Vez (2010), the paradigm of languages focuses on considering languages as basic goods, with an intrinsic utility that the state must give to its citizens. Hence, once again, the instruction of English was prioritized through the enactment of a bilingualism law and four national bilingualism programs, which shared the objective of inserting Colombian human capital into the international dynamics by fostering communicative skills in English (Gómez Sará, 2017). De Mejía (2005, as cited in Valencia, 2013) asserted that individuals that possess the symbolic resource of being highly competent in English could easily gain access to other valuable, educational, and material or symbolic resources' (p. 2).

The strong influence of globalization on the country forces Colombians to learn English, which can sometimes be a hard decision because they do not feel the necessity to communicate in a foreign language, but rather to get a good job. In Interviewee 1's words, college students have to learn English because Colombian educational policies demand it. In addition, they know that if students want to have a better job or apply for a scholarship, they must learn English.

“... English gives you the opportunity to improve your status. If a person is interested in joining an important company, he or she will need to speak English fluently.” (INTVW. 1)

In addition, Interviewee 1 asserts that English is an important language for connecting with people from other countries: "English is important to understand other cultures" (INTVW, 1).

In Ramírez's words (2015), this means that 'English contributes with a sophisticated form of linguistic colonialism and cultural invasion; it seems that English acts as a passport to higher cultural, political and economic levels, replicating an ideal common culture' (p. 30).

Conversely, English language learning in the country generates some discomfort among students, teachers, and parents because of the lack of pertinence in social contexts. Thus, Interviewee 6 says:

"Although there is great concern in the rural contexts, we usually think erroneously that learning English is not necessary in those places, we do not find a real purpose. Students ask 'Why do I 
have to learn English if I don't need it... Even it does not represent any benefit for me..." (INTVW. 6)

In addition, Interviewee 9 claims that Colombian social and economic conditions limit the interest of students in learning English and explains curricular aspects that make teachers include English language in their classes because educational policies demand it, but not because they are responding to the social necessities of students:

"We have not studied the sociocultural situation that our students experience once they start learning a new language. We have forgotten that the student also takes part in this process. Our culture is a culture more of dependence than of independence and autonomy." (INTVW. 9)

\section{TLEFL in Colombia}

\section{Pedagogy, Didactics, and Linguistics - Approaches and Methods}

Interviewee 2 highlights the situation of undergraduate and postgraduate programs, which are trying to encourage changes in the perception of teaching and learning English that have an impact on what is happening inside the classroom and attend to the social and cultural problems students and teachers face every day. This participant asserts that:

"In our teaching training programs, the applied linguistics is no longer a theoretical subject and it is like transitioning to what it would be called critical applied linguistics; but not only to promote critical thinking as is traditionally conceived, but to develop that sensitivity to social and cultural problems; we must think of a transdisciplinary approach.” (INTVW 2)

In reference to the approach and methodology used, TLEFL in Colombia has been marked by foreign and prescriptive approaches based on a set of fixed rules. As stated by interviewee 10, teaching English is seen as a weak and little explored field that does not have strong foundations and ends up adopting foreign methodologies that are in fashion: "Colombia assumes teaching methodologies as methodological fashions, these trends bring money, which is captured through publishers, and also bring instrumental models of how to teach a language" (INTVW. 10).

On the other hand, participants assert that the MEN proposes reforms that are mostly copied from elsewhere, but these reforms do not necessarily reflect our needs. For example, in the CEFR, some levels are required, but this framework arose in a hugely different context from that of Colombia. Besides, some participants asserted that a structural approach to teaching language is still present in classrooms. As interviewee 8 stated: "Those programs are basically a functional prison of the language; so, you keep looking at English as an 
Martha Isabel Bonilla-Mora,

Johanna Patricia López-Urbina

instrument to order in a restaurant, to make a call... as if language were isolated from a context." (INTVW. 8)

As regards the methods, Bastidas (1989) affirms that the teaching and learning of foreign languages in each country have complex features, and that is why a preservice teacher must know in depth all the methods. If teachers in training do not know them, they cannot apply the eclectic method and should not expect good results in class; otherwise, the eclectic method cannot be put into practice. Thus, Interviewee 10 affirms:

'We cannot forget the 'how to teach foreign languages', this, because our students will go out and teach English, and it is important for them to consider the no parametric, methodologies. Right now, for example, Kumaravadivelu proposes the post-method and emerging teaching. We should not forget that we do not only teach a foreign language, but we teach communication; at the end of the day, what a person wants to do when he or she learns a language is to communicate." (INTVW. 10)

\section{Teaching and Evaluation Standards}

Regarding the national policies, specifically the 'Basic Standards of Competence in a Foreign Language: English' (MEN, 2006), we can identify that this policy assumes the learning of foreign language in a very structural way and makes the student of English appropriate language as a system. Vez (2010) affirms that teachers should not forget that 'standards' means the instrumentalization of the teaching and learning of a language. In addition, Usma Wilches (2009) realizes that the standards and evaluation had become like mechanisms of control and exclusion. From this perspective, the learning of a foreign language frames a deficit perspective, in which language is seen as a competence or a skill to be developed. Interviewee 3 affirms standards have been conceived from a deficient perspective of language:

"When I read the standards of English and I compare them with the standards of other areas, like biology, I see that these last ones were thought [out] ... from a scientific perspective in which they can experiment, to create, to be critic [al] ... while English standards are thought [out] only at the level of the ability to appropriate language as a system.” [sic] (INTVW 3)

For his part, Ramírez (2015) states 'the view of language expressed in Basic Standards perpetuates the vision of language as neutral' (p. 50). Pennycook (1994, as cited in Guerrero Nieto \& Quintero Polo, 2009) asserts that the neutrality of English emerged from two main discourses: the discourse of linguistics and applied linguistics, in which language was a medium for communication, and the discourse of marketing, in which English, along with all the activities related to it, such as teaching methodologies, textbooks, teacher training, tests, materials, etc., are portrayed as a service industry. 


\section{Colombian English Teachers' Identities}

Interviewee 7 asserts that teachers have a minimal role when facing governmental policies. The participant states that national policies do not involve the concept of teachers as individual and beings, but as reproducers of the knowledge that the policy is requiring from them: "Teachers are not stupid, nor manipulable in the face of policies ... they react and there are proposals of resistance" [sic] (INTVW. 7).

This allows us to understand how teachers enter serious conflicts with themselves when they must accept something that they do not agree with: "It is interesting to analyze how policies generates an inner discomfort and conflict among teachers because they are forced to accept and apply policies they are not agree with" [sic] (INTVW. 2).

\section{TLEFL Contexts in Colombia}

\section{Elementary and High School Contexts}

Interviewee 3 affirms that it is necessary to redesign the national policies regarding the TLEFL in elementary school. Elementary teachers in Colombia have valuable experience in how to teach children, but the MEN often simplifies their level of knowledge just because they do not know English. Interviewee 3 presents the origin of the problem. In Colombia, elementary teachers who do not have enough knowledge to teach a language must give English classes to their students. On the other hand, although the MEN is aware of this serious situation, it is not willing to hire expert people in the field, arguing a lack of financial resources. In some cases, that situation could be one of the reasons why English levels in these grades are deficient in some Colombian public schools.

According to Guerrero and Maturana (2011), graduates in English are usually assigned to high schools, paradoxically aggravating the problem since the role of the teacher in the basic years of education is essential. This happens in elementary and secondary grades in the rural areas of Colombia.

Colombia's characteristics affect the process of learning inside the classroom as well. When Interviewee 9 was asked for the perception of the teaching and learning of a foreign language in rural areas, this teacher explained that, in some regions, children are forced to leave or pause their education process because they need to work and help their parents in the countryside jobs. In some cases, they are even taken to work in the manufacturing process of illegal drugs. This interviewee states the following:

"Rural education is perhaps the most neglected area and has not really dabbled in the research in EFL. There, the development of linguistic competences in English is minimal, because of the 
Martha Isabel Bonilla-Mora,

Johanna Patricia López-Urbina

complexity of our country. When I listen to the graduated teachers, they say 'teacher, what you teach us in class it is important... But, what can we do when students are absent for a month in my school because they must collect coca in Putumayo?' This means they face difficult circumstances to get good results, not only in English, but in education in general.” [sic] (INTVW. 9)

\section{Bachelor Programs and Superior Studies Contexts}

According to González (2007), the professional development of teachers is a constant concern in research related to EFL but in some cases, the teaching of English as a professional activity in Colombia has not really emerged from the local knowledge.

On her part, Interviewee 3 expresses a lack of relationship between the contextual and previous knowledge of students and the principles of Foreign Languages National curricula. Even though most of the experts are aware of the positive changes English language bachelor degree programs have had in the last few years, interviewee 3 claims that including a stronger practical approach in the curriculum is necessary, and more importantly in the national English programs. The teacher states that pre-service teachers experience a shock when they need to put into practice all the theory that they learned during their major because of the lack of knowledge related to the realities they face in their contexts. In the following excerpt, the interviewee 3 paraphrases a student's opinion:

"Teachers never teach us that we must go to know the place where the school is located or that we must arrive and go to look and know what the school is, its surroundings, the neighborhood, etc., to be able to locate and know our apprentices, to be able to locate them and be able to adapt the curriculum, teach, build the curriculum. We do not know how to build the curriculum; we do not know how to articulate the standards of student reality and the school environment..." (INTVW. 3)

The teacher also asserts that there is a big failure in the teaching practices and the teachers in charge of the training. Therefore, it is crucial that teachers reconsider the teachers' training processes:

"It turns out that the teacher who speaks less English is assigned to teach in the basic level, and the other who speaks a little more oversees the intermediate level... we are not making good decisions on how and with whom we should count on this learning process and ... the way we can help improve that human resource so and the way we can impact the learning context. The quality of education is badly conceived. I think we are really forming some graduates whose proficiency in English is good, but their pedagogical and their curricular skills need to be improved... we are not teaching pedagogy, nor are we teaching curricular design.” [sic] (INTVW. 3)

On the contrary, participant 2 affirms that we have shreds of evidence of a good teacher's formation in the Bachelor's degree program in EFL education. For example, the participant says that future teachers are now more critical and more proactive. Nowadays, 
pre-service teachers do not see teaching to be instrumental as it used to be. However, the interviewee exhorts other teachers to reflect on how students can be motivated to think epistemologically and logically. The answer must consider a different vision of language and create new social constructs. This participant states:

"So now, we are already seeing in the teacher training programs, future teachers with a slightly more critical spirit who are beginning to make question, etc. and they begin to propose in their degree projects alternative subjects, subjects no longer seeing language as instrumental as it was seen before. But it goes a little further, again epistemologically speaking. They already have a vision of language different from language as the object of study, but rather to consider language as a vehicle for creating new knowledge, for establishing social relationships and so on.... well, it is fortunate that there are such initiatives, but they are still isolated efforts in the different universities, but I would like it to be of general application.” [sic] (INTVW 2)

\section{State of Bilingualism in Colombia}

During the interviews, participants recognized a wider understanding of what bilingualism means in education policies, beyond the relation of English and Spanish in the national curriculum. They also claimed the need to conceive Colombia as a bilingual, and plurilingual country, considering the indigenous languages that coexist in our territory. Thus, interviewee 2 harshly criticizes the simple concept of bilingualism upon which the government has based the creation of national linguistic policies:

"The concept of bilingualism that was initially managed by the MEN was a misconception, so the concept of bilingual education wasn't also very successful (...) There are still problems with the goal of Colombia as a bilingual nation in a short time as a result of a decree or a law (...) We could say that Colombia is not a bilingual country when referring to English; and indeed, from the linguistic, from the epistemological point of view, Colombia is not a bilingual country but a multilingual, because here we cohabit with many other languages apart from Spanish. However, for certain representatives of the government indigenous languages are not even considered languages, they are sometimes regarded as exotic dialects... that is another way of invisibilizing." [sic] (INTVW 2)

This point of view is shared by other participants who claimed in their interviews that the English language, as a prestige language, cannot be the only solution to achieving bilingualism in Colombia. For example, Interviewee 3 illustrated it in the following way:

"But why bilingualism in Spanish-English? Why a prestigious bilingualism? ... I believe that the training of teachers must be extended to a more critical view of the conception of languages, so teachers should not assume themselves they are better than others are because they speak English, or because they know the prestige language. We must be binding in the languages and diversity of the population we have in our classrooms. We are not living a bilingualism. Even bilingual schools that define bilingualism from their practices, do not graduate bilingual children." [sic] (INTVW. 3) 
Martha Isabel Bonilla-Mora,

Johanna Patricia López-Urbina

In Colombia, English language proficiency levels in high schools are measured by means of standardized tests called Pruebas Saber, which have shown that these levels of Colombian students are lower or have stayed the same during the last years. For instance, Interviewee 9 asserts that there has not been a significant improvement in results from the implementation of the bilingualism programs in Colombia:

"Despite Colombia has a national bilingual program, Governmental quality tests, like ICFES which are aligned with British tests, demonstrate that the level of bilingualism remains the same before and after the National Program, or perhaps a little lower according to the results these last few years. It means that our concern would be to see how we can explain the phenomenon of minimum learning that occurred after the General Education Law which introduced English learning in primary school." [sic] (INTVW. 9)

Participants also stated that TLEFL arrived in Colombia because of globalization demands. Unfortunately, bilingualism programs do not deal with the necessities of the regions but rather they replicate foreign approaches. Interviewee 3 affirms:

"[When talking about the PNB] Almost every year we have a different goal, date, and name. Since 2000 , a thousand projects have been created ... So, each time we are forced to change all that, and this has been reflected in the local politics; for example, Machetá ${ }^{4}$ bilingual or Pacho bilingual. Regions have tried to replicate these models at the local level. Then, English was given by means of globalization and replaced the teaching of other languages that once were important historically talking." [sic] (INTVW. 3)

This previous position goes hand in hand with what Usma Wilches (2009) points out: that the purpose of teaching and learning a language should not be to get out of poverty or solve economic problems - this brings an illusion of investment in English.

Regarding further education within the bachelor programs of Colombian universities, the situation seems to be similar to what is happening in public schools. According to Interviewee 9, despite the advancement that further education has had, we cannot affirm that all the students from bachelor programs in Colombia have a C1 level of English proficiency according to the CEFR or even a B2. There is a lot of research on this situation in national scientific journals, in which teachers' evidence a problem in fulfilling the policies established by the MEN for the Bachelor Teaching Programs. This interviewee affirms:

"For example, we have shown that, in the same colleges where we offer bachelor's degrees in the English or French language, we are failing to show that all the students acquire a language level that places them according to the CEFR, at least in a B2 level. But we do not know what to do when the ministry has drawn a standard that states students must graduate with a C1 level. I have had the opportunity to visit several colleges since 2005 for academic high-quality purposes and I

Machetá is a town in Colombia in the department of Cundinamarca. 
have not found any institution that shows that all its students are in C1 level, in the international standards exams, of course. In other bachelor programs, it is worse." [sic] (INTVW 9)

Nevertheless, participants are not completely negative about the results of the previous bilingualism programs the MEN has launched for the sake of improving the TLEFL in our country. Some of them highlight certain advancements, such as the inclusion of a compulsory foreign language in the national curriculum, a better level of English proficiency of teachers, a slight improvement in the level of English language of public school students, and an increase in hours in English classes, although they are not enough. However, they emphasize that there are some core problems that have not been solved. For example, Interviewee 10 states:

"The underlying problem has not been solved. There are many other vicissitudes that Colombia has. Public policy focused on making people speak English when people do not need it (...) and the peasants who are in Boyacá, Amazonas, among others, need another type of bilingualism. Here [in Bogotá] we teach English and Spanish, but those who live in Leticia that have a border with Brazil, they need bilingual tests in Portuguese. There is an interesting space of bilingualism called border bilingualism. So, Colombia needs to define the type of bilingualism.” [sic] (INTVW. 10)

\section{Discussion and Conclusions}

In reference to the research question, what are the local epistemological perceptions that underlie the teaching and learning of EFL in Colombia nowadays, data analysis showed that the participants of this study and previous authors consider that there are still weaknesses in the definition of a didactic in EFL that addresses the real needs of the Colombian context (Guerrero, 2010; Guerrero \& Maturana, 2011). In addition, the policies demonstrate that TLEFL are still permeated by economic and political interests. Regarding the epistemology of foreign language teaching, analysis demonstrates that Colombia has not escaped from the adoption of foreign models. Teaching and learning are seen as a weak and little explored field, characterized by a denotative function that makes teachers and learners consumers of information, leaving no space for teachers to develop an awareness of the hegemony of English (Cárdenas, 2006; González, 2010; Guerrero, 2010; Robayo-Acuña \& Cárdenas, 2017).

According to the literature review (Rincón \& Clavijo Olarte, 2016; Fandiño-Parra, 2014) and the perceptions of the interviewees, the way in which the teaching and learning of English is taught and conceived in our country has changed. In the previous century TLEFL was more understood as a deepening of the theoretical foundations of teaching; a fact that caused a great consumption of methodologies, approaches, and methods that came from foreign countries. 
The teaching of English as a foreign language is now perceived as a practical and critical process. Experts in the field today advocate linking English learning with the real contexts and situations of students, whether political, social, or educational (Kumaravadivelu, 2016; Granados-Beltran, 2018a). There must be a collaborative work between foreign and national pedagogical practices to achieve a meaningful learning of the foreign language. In addition, for decades there has been a need to rethink the teaching and learning of English from a transdisciplinary point of view, but this concept is one of the aspects that requires new proposals regarding its development and inclusion in the classroom.

Teacher identity gives teachers the right to sustain who they are (Castañeda-Peña et al. 2016), so it is crucial teachers develop strategies by which they can construct new understandings of classroom practices and at the same time shape their identity based on their life's experiences. This perhaps is the most important capability that teachers need: to satisfy teaching necessities in a changing and disruptive world (Guerrero \& Maturana, 2011).

A reiterative position from the participants of this study points out the necessity of having a dialogue and agreement between teachers and governmental representatives so that they can define policies that benefit Colombian citizens and not just economic sectors of the country. Ignoring experiences, identities, and complexities of the different learning contexts of our country becomes a relevant factor at the time of determining why policies, decrees, projects, and bilingualism plans have not gotten the results policymakers projected when English was enacted as the official language to be included in the National Education System. Additionally, it is compulsory to revise and redesign the language education policy, so it includes not only dominant and prestige languages, but also considers and plans an investment in achieving an equality among languages, be they foreign or native languages.

The interest in including English as a foreign language in the curriculum emerged thanks to the globalization movements in which the country has been immersed. This contributed to the diffusion of knowledge, which means the dominance of English as an international language, leaving aside the recognition of the cultural characteristics of our country, as well as the marginalization of communities and languages that exist in the territory. Apart from considering TLEFL in Colombia as a great world power, English has also been considered a basic good that confers prestige. This prestige of being proficient

28 in English is a part of the symbolic capital. In this way, we intend to put on the agenda the possibility of conceptualizing the learning and teaching of foreign languages, and of any language in the national territory from an ecological position, for instance, which recognizes our multiculturalism, multilingualism, our rurality, and complexity.

Promoting continuous training for English teachers is necessary as well; training based on real learning contexts, a critical position towards theory and learning methods, and the promotion of situated learning of foreign languages. Regarding this idea, the participants 
stated that pedagogical practices need to approach their programs with the heuristic development of the teacher. These practices must be based on teaching methods that will allow teachers to cope with the different aspects, issues, or necessities that diverse contexts can present.

Based on the theory and the findings, teachers are exhorted to carry out meaningful teaching practices and to raise awareness related to the construction of the self and knowledge. So, we settle the necessity of working on an epistemological reconstruction that involves, for example, the ecology of knowledge, that engage critical knowledges and practices, leaving apart the Eurocentric vision.

Finally, the authors reiterate the importance of this study when considering the period of validity of the present National Plan of Bilingualism, 2018-2022, presenting an updated state of the art of the current situations teachers and students face while teaching and learning English as a foreign language in Colombia. At the time of closing this article, Colombia and the entire world are under the effects of COVID 19, and this makes it mandatory to re-think new language policies.

\section{References}

Bastidas, J. (1989). El método ecléctico. Revista Hechos y Proyecciones del Lenguaje, 31-38.

Bastidas, J. A. (2017). More than half a century teaching EFL in Colombian secondary schools: Tracing back our footprints to understand the present. HOW, 24(1), 10-26. https://doi. org/10.19183/how.24.1.348

Bonilla Carvajal, C. \& Tejada-Sánchez, I. (2016). Unanswered questions in Colombia's foreign language education policy. Profile Issues in Teachers` Professional Development, 18(1), 185-201. https://dx.doi.org/10.15446/profile.v18n1.51996

Bonilla, M., López, J., \& Caro, H. (2018). Teaching and learning English as a foreign language in a pluricultural context: A historical and normative Colombian background. ICERI2018 Proceedings, 8653-8663. https://doi.org/10.21125/iceri.2018.0592

Cárdenas, M. L. (2006). Bilingual Colombia: Are we ready for it? What is needed? Proceedings of the 19th Annual English Australia Education Conference. http://qa.englishaustralia.com.au/ index.cgi? $\mathrm{E}=$ hcatfuncs $\& \mathrm{PT}=$ sl\&X=getdoc\&Lev1=pub_c07_07\&Lev2=c06_carde

Castañeda-Peña, H., Rodríguez-Uribe, M., Salazar-Sierra, A., \& Chala-Bejarano, P. A. (2016). Narrative events of pre-service teachers at the end of their teaching practicum with regard to their pedagogical advisor: Learnings reported. Signo y Pensamiento, XXXV(68), 52-64.

Charmaz, K. (2006). Constructing grounded theory: A practical guide through qualitative analysis. Sage.

Colombia Aprende (2016). Plan Nacional de Bilingüismo: Conozca el Plan Nacional de Bilingüismo. https://aprende.colombiaaprende.edu.co/es/colombiabilingue/86689 
Martha Isabel Bonilla-Mora,

Johanna Patricia López-Urbina

Creswell, J., \& Miller, D. (2000). Determining validity in qualitative inquiry. Theory into Practice. Educational Practice, (Summer), 124-130. https://doi.org/10.1207/s15430421tip3903_2

Creswell, J. W. (2007). Qualitative inquiry \& research design choosing among five approaches (2 ${ }^{\text {nd }}$ ed.). SAGE.

Creswell, J. W. (2013). Qualitative inquiry \& research design choosing among five approaches (3 ${ }^{\text {rd }}$ ed.). SAGE.

Fandiño-Parra, Y. J. (2014). Bogotá bilingüe: Tensión entre política, currículo y realidad escolar. Educ. Educ. 17(2), 215-236.

Ferraris, M. (1996). History of hermeneutics (Luca Somigli, Trans.). Humanities Press.

Gómez Sará, M. M. (2017). Review and analysis of the Colombian foreign language bilingualism policies and plans. HOW, 24(1), 139-156. https://doi.org/10.19183/how.24.1.343

González, A. (2007). Professional development of EFL teachers in Colombia: Between colonial and local practices. Íkala, Revista de Lenguaje y Cultura, 12(18), 309-331.

González, A. (2010). English and English teaching in Colombia: Tensions and possibilities in the expanding circle. In A. Kirkpatrick (Ed.), The Routledge handbook of world Englishes (pp. 332 351). Routledge.

Granados-Beltrán, C. (2018a). Revisiting the need for critical research in undergraduate Colombian English language teaching. HOW, 25(1), 174-193. https://doi.org/10.19183/how.25.1.355

Granados Beltrán, C. (2018b). La interculturalidad crítica en los programas de formación inicial de docentes de las lenguas extranjeras en el contexto colombiano contemporáneo. [Doctoral dissertation, Universidad Santo Tomás]. CRAI USTA http://hdl.handle.net/11634/15503

Guerrero Nieto, C. H., \& Quintero Polo, Á. H. (2009). English as a neutral language in the Colombian national standards: A constituent of dominance in English language education. Profile: Issues in Teachers' Professional Development, 11(2), 135-150.

Guerrero, C. H., \& Maturana, L. M. (2011). Teaching English in times of the National Bilingual Program in some state schools: Linguistic and pedagogical factors. Colombian Applied Linguistics Journal, 13(2), 74-87.

Guerrero, C. H. (2010). The portrayal of EFL teachers in official discourse: The perpetuation of disdain. Profile: Issues in Teachers' Professional Development, 12(2), 33-49.

Hakuta, K. (2009). Bilingualism. In L. R. Squire (Ed.), Encyclopedia of Neuroscience (pp. 173178). Academic Press. https://doi.org/10.1016/B978-008045046-9.01877-5

Junca, J. (2016). El bilingüismo en el contexto colombiano. In C. A. Camacho Sanabria (Ed.), Reflexiones para una epistemología del saber pedagógico (pp. 93-110). Ediciones Unisalle. https://doi. org/10.19052/238237206

Kumaravadivelu, B. (2016). The decolonial option in English teaching: Can the subaltern act? TESOL Quarterly, 50(1), 66-85. https://doi.org/10.1002/tesq.202

Ministry of National Education (1994). Ley 115. Santafé de Bogotá, Colombia

Ministry of National Education (2006). Estándares Básicos de Competencias en Lengua Extranjera: inglés [Cartilla 22]. Imprenta Nacional 
Ramírez, L. D. (2015). Foreign language education in Colombia: A case study. Perceptions of Foreign Language policy. Lambert Academic Publishing.

Rincón, J., \& Clavijo-Olarte, A. (2016). Fostering EFL learners' literacies through local inquiry in a multimodal experience. Colombian Applied Linguistics Journal, 18(2), 67-82. https://doi. org/10.14483/calj.v18n2.10610

Robayo-Acuña, L. M., \& Cárdenas, M. L. (2017). Inclusive education and ELT policies in Colombia: Views from Some PROFILE Journal Authors. Profile: Issues in Teachers' Professional Development, 19(1), 121-136. https://doi.org/10.15446/profile.v19n1.61075

Soleimani, N. (2018). ELT teachers' epistemological beliefs and dominant teaching style: a mixed method research. Asian. J. Second. Foreign. Lang. Educ. 5, 12. https://doi.org/10.1186/s40862020-00094-y

Scotland, J. (2012). Exploring the philosophical underpinnings of research: Relating ontology and epistemology to the methodology and methods of the scientific, interpretive, and critical research paradigms. English Language Teaching, 5(9), 9-16. http:/ /dx.doi.org/10.5539/elt.v5n9p9

Usma Wilches, J. A. (2009). Education and language policy in Colombia: Exploring processes of inclusion, exclusion, and stratification in times of global reform. Profile: Issues in Teachers' Professional Development, 11(1), 123-141.

Valencia, M. (2013). Language policy and the manufacturing of consent for foreign intervention in Colombia. Profile: Issues in Teachers' Professional Development, 15(1), 27-43.

Vez, J. M. (2010). Paradigmas en la enseñanza de lenguas extranjeras. Asociación Europea de Profesores de Español. Del XLV Congreso Internacional de la AEPE. Congreso llevado a cabo en la ciudad de la Coruña, España.

Watson-Gegeo, K. (2004). Mind, language, and epistemology: Toward a language socialization paradigm for SLA. The Modern Language Journal. 88, 331-350. 